\title{
Volatile chemical composition of Colombian Piper gorgonillense Trel. \& Yunck. essential oil and its repellent and fumigant activity against Tribolium castaneum Herbst
}

\section{Composición química volátil del aceite esencial colombiano de Piper gorgonillense Trel. \& Yunck. y su actividad repelente y fumigante contra el Tribolium castaneum Herbst}

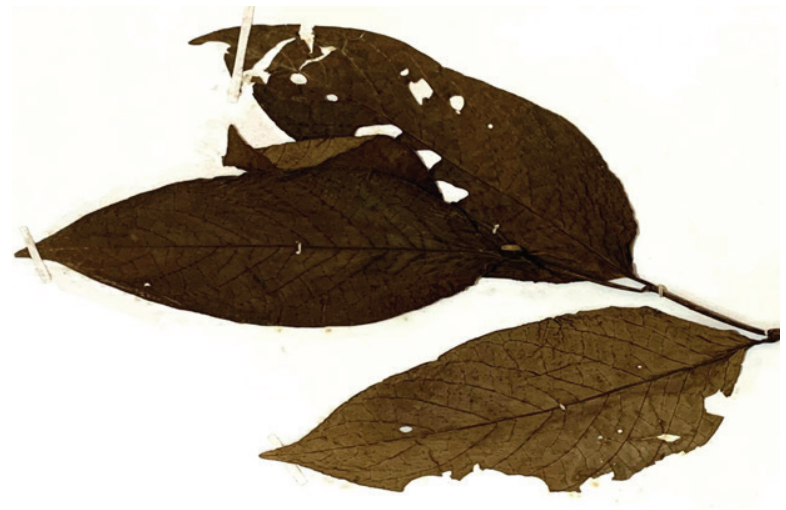

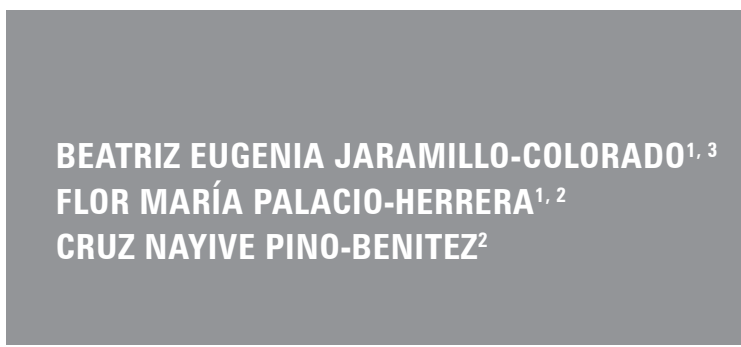

Piper gorgonillense Trel. \& Yunck.

Source: Herbarium of Universidad Tecnológica del Choco Diego Luis Córdoba (No. 11990) herbarium of the Universidad de Antioquia (No-493853)

\begin{abstract}
Essential oils (EOs) are mixtures of volatile organic compounds, mostly terpenes, from the secondary metabolism of plants. These oils exert various activities on insects that damage crops and cause losses worldwide for the economy and agriculture. Tribolium castaneum Herbst (Coleoptera: Tenebrionidae) is one of the main pests causing the loss of a large amount of stored food. The objective of this study was to evaluate the volatile chemical composition of the essential oil from Piper gorgonillense Trel. \& Yunck. and its repellent and fumigant activity on $T$. castaneum. The volatile composition was determined with gas chromatography coupled to mass spectrometry. The majority compounds found in the EO were $\beta$-caryophyllene (28.7\%), $\alpha$-copaene (13.5\%), and $\delta$-cadinene $(7.3 \%)$. The repellency percentages obtained were 78 and $90 \%$ at a concentration of $1 \%$ with exposure times of 48 and 72 hours, respectively. The fumigant activity refers to the insecticidal action that an essential oil vapor can have without coming into direct contact with insects; this was $100 \%$ at a concentration of EO $350 \mu \mathrm{g} \mathrm{mL}^{-1}$. The results showed that the $P$. gorgonillense EO had repellent and insecticidal properties for the biological control of T. castaneum.
\end{abstract}

Universidad de Cartagena, Faculty of Exact and Natural Sciences, Cartagena (Colombia). ORCID Jaramillo-Colorado B.E.: 0000-0003-1708-2367; ORCID Palacio-Herrera. F.M.: 0000-0001-9106-0161

2 Universidad Tecnológica del Choco Diego Luis Córdoba, Faculty of Education Sciences, Quibdo (Colombia). ORCID Pino-Benítez, C.N.: 0000-0001-7471-8697

3 Corresponding author.bjaramilloc@unicartagena.edu.co 
Additional keywords: essential oil crops; repellency; mortality; terpenes; gas chromatography.

\section{RESUMEN}

Los aceites esenciales (AEs) son mezclas de compuestos orgánicos volátiles, en su mayoría terpenos, provenientes del metabolismo secundario de las plantas. Estos tienen diversas actividades sobre insectos que dañan las cosechas y producen grandes pérdidas en la economía y la agricultura mundial. El Tribolium castaneum Herbst (Coleoptera: Tenebrionidae), es una de las principales plagas causante de la pérdida de gran cantidad de alimentos almacenados. El objetivo de este estudio fue evaluar la composición química volátil del aceite esencial de Piper gorgonillense Trel. \& Yunck. y su actividad repelente y fumigante sobre el T. castaneum. La composición volátil se determinó empleando cromatografía de gases acoplada a espectrometría de masas. Los compuestos mayoritarios encontrados en el AE fueron $\beta$-cariofileno (28.7\%), $\alpha$-copaeno (13.5\%), y $\delta$-cadinene $(7.3 \%)$. Los porcentajes de repelencia obtenidos fueron de 78 y $90 \%$ a una concentración de 1\% con tiempos de exposición de 48 y 72 horas, respectivamente. La actividad fumigante hace referencia a la acción insecticida que tiene el vapor del aceite esencial sin tener contacto directo con los insectos, este fue de $100 \%$ a una concentración de $350 \mu \mathrm{g} \mathrm{mL} \mathrm{mL}^{-1}$. Los resultados mostraron que el AE de P. gorgonillense presentó propiedades repelentes e insecticidas para el control biológico de T. castaneum.

Palabras clave adicionales: aceite esencial de cultivos; repelencia; mortalidad; terpenos; cromatografía de gases.

Received for publication: 31-05-2020 Accepted for publication: 23-11-2020

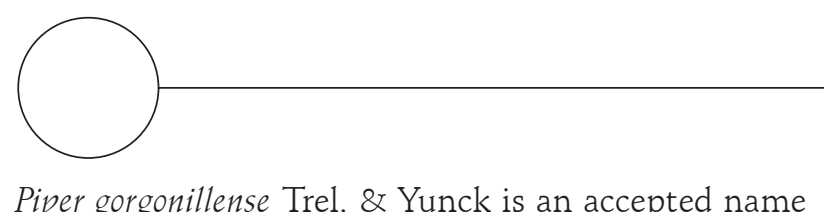

for a species in the Piper genus (Piperaceae family) (The Plant List, 2013). It is a bush native to Colombia that can reach $3 \mathrm{~m}$, which has been found in the canyon and valley of Bajo Cauca, valley of Magdalena Medio, the jungle valley of Atrato and Uraba (0-500 $m$ altitude), eastern slope of the Central Mountain Range or Cordillera Central $(0-1,000 \mathrm{~m})$, and the Nariño department (Idárraga and Callejas, 2011). Plants of the Piper genus have shown various biological activities, such as anti-inflammatory (Rengifo et al; 2019), phytotoxic, antifungal (Parra et al., 2019), antimicrobial (Gamboa et al., 2018), repellent and insecticidal properties (Jaramillo-Colorado et al., 2019a; Chaubey; 2011), among others. Approximately, two hundred and fifty species of insects attack grains and their products during storage, of which around twenty are of paramount importance (Opit et al., 2012); among these, one of the most damaging is the brown flour beetle, whose common name comes from its color and its habits of infesting flour, while its scientific name is Tribolium castaneum Herbst. This beetle belongs to the Insect class, Coleoptera order and Tenebrionidae family (Athanassiou et al., 2016). It is one of the most important stored product blights found in homes and grocery stores. It has an Indo-Australian origin and currently occurs worldwide in warmer climates. T. castaneum Herbst is a secondary pest that generally feeds on stored cereals and grains (Adamski et al., 2019).

To minimize these losses, chemical pesticides are normally used, where mixtures of insecticides and fungicides are utilized in order to protect the seeds during storage; however, chemicals can generate seed toxicity and lead to resistance problems, environmental contamination, and food residues (Daglish et al., 2015). Several authors have reported the use of essential oils as a non-chemical option for the management of these insect pests (Singh and Pandey, 2018; Andrés et al., 2017). EOs are obtained from aromatic plants and are made up of different volatile organic compounds, so their biological activities will rely on their composition and the interaction between their components (Kendra et al., 2017).

The objective of this study was to determine the volatile chemical composition of the essential oil from $P$. gorgonillense by assessing its repellent and fumigant activity against $T$. castaneum. 


\section{MATERIALS AND METHODS}

\section{Reagents and chemicals}

Anhydrous $\mathrm{Na}_{2} \mathrm{SO}_{4}$ was acquired from Merck (Darmstadt, Germany). Dichloromethane, acetone, and hexane were acquired from AppliChem Panreac (Darmstadt, Germany), along with DEET (Dr. Ehrenstorfer, Germany) and pirimiphos methyl (Syngenta, Colombia). Filter paper was purchased from GE Healthcare (Hangzhou, China).

\section{Vegetal material}

Fresh Piper gorgonillense Trel. \& Yunck. leaves and stems were collected in a rural area of Quibdo (Colombia) in July 2018. The collection site is characterized as a growing area and is also vulnerable to flooding. Taxonomic identification was done at the Herbarium Universidad de Antioquia. The control leaves of each plant are archived as a permanent sample at the Herbarium (No-493853).

\section{Extraction of the essential oil}

The extraction was performed using the hydrodistillation technique, according to Jaramillo-Colorado et al. (2012). $500 \mathrm{~g}$ of leaves and stems from P. gorgonillense were used, finely chopped and submerged in boiling water with conventional heating for $2 \mathrm{~h}$. The EO was separated with decantation, and then anhydrous $\mathrm{Na}_{2} \mathrm{SO}_{4}$ was added to the oil. One $\mathrm{EO}$ aliquot $(30 \mu \mathrm{L})$ was diluted in one $\mathrm{mL}$ of dichloromethane for the gas chromatography analysis (Jaramillo et al., 2020).

\section{Chromatography analysis}

The EO was analyzed in an Agilent Technologies GCMS system model 7890A Network GC coupled to a mass selective detector model 5975 (Palo Alto, CA) equipped with a split/split-less injection port $\left(230^{\circ} \mathrm{C}\right.$, split ratio 20:1). The mass spectra were obtained with electron-impact ionization at $70 \mathrm{eV}$ energy. The GC conditions were as follows: A HP-5MS capillary column (30 m $\times 0.25 \mathrm{~mm}$ id $\times 0.25 \mu \mathrm{m} \mathrm{df}$ ) with $5 \%$ phenyl-poly (methyl siloxane) stationary phase was used for the separation of mixtures. The initial oven temperature was $50^{\circ} \mathrm{C}$ for $2 \mathrm{~min}$, increased at a rate of $5^{\circ} \mathrm{C}$ min up to $250^{\circ} \mathrm{C}$ (5 min). The carrier gas was helium, with an inlet pressure at the head of the column of $12.667 \mathrm{psi}$ at a rate of $1.172 \mathrm{~mL} \mathrm{~min}^{-1}$, at $50^{\circ} \mathrm{C}$. The mass spectra and Kovàts retention indexes were compared to those reported in the literature (Adams, 2007).

\section{Insects and bioassays}

T. castaneum adults were collected $7 \mathrm{~d}$ after hatching. Bioassays were carried out in the dark in incubators at $28-30^{\circ} \mathrm{C}$ and $70-80 \%$ relative humidity at the Agrochemical Research Laboratory of the University of Cartagena. Oat (Avena sativa) was used to feed T. castaneum.

\section{Repellent activity}

The repellent property of $P$. gorgonillense EO was analyzed on adult specimens of $T$. castaneum using the area preference method. The P. gorgonillense EO was dissolved in acetone after preparing five solutions $(1,0.1,0.01,0.001$, and $0.0001 \%)$. A filter paper of $9-\mathrm{cm}$ diameter sheet was cut in half, and $500 \mu \mathrm{L}$ of each concentration was applied separately to one of the halves of the filter paper as evenly as possible with a micropipette. The other half (control) was treated with $500 \mu \mathrm{L}$ of acetone. DEET (N, N-diethyltoluamide), a commercial repellent, was the positive control.

The treated and control media disks were dried at room temperature for $10 \mathrm{~min}$ to allow the solvent to evaporate. The treated and untreated halves were attached using adhesive tape and placed on Petri dishes. Twenty adult specimens (5 to $7 \mathrm{~d}$ old) of $T$. castaneum were placed, one by one, in the center of each filter paper disc with the help of tweezers. The dishes were then covered and, after approximately $5 \mathrm{~min}$, transferred to an incubator at room temperature (Jaramillo-Colorado et al., 2019b). Four replicates were used for each concentration. The weevil preference was measured for each Petri dish at 2 and 4 h of exposure.

The following equation was used to determine the percentage of repellency (PR), following the parameters identified by Jaramillo-Colorado et al. (2012) (Eq. 1):

$$
\mathrm{PR}=[(N c-N t) /(N c+N t)] \times 100
$$

where, Nc is the number of insects in the control area (acetone), and $N t$ is the number of insects in the treated area (EO + acetone). 


\section{Fumigant activity}

Fumigant activity was performed according to Jaramillo-Colorado et al. (2019b). The toxic effect of $P$. gorgonillense EO and terpenes were assayed on T. castaneum. Filter paper discs (Whatman No. 1, 2-cm in diameter) were laid down at the bottom of Petri dish covers $(90 \times 15 \mathrm{~mm}$ ), which were impregnated with oil at doses calculated to provide equivalent fumigant concentrations of 500,350, 250,150, $50 \mu \mathrm{g} \mathrm{mL}^{-1}$ air of oil, respectively. Twenty adult insects (1 to 10 days old) were introduced and tightly capped (replicated four times for each concentration). Pirilan, a commercial pesticide containing methyl pirimiphos (Syngenta, Colombia) (organophosphorus pesticide, $300 \mu \mathrm{g} \mathrm{L}^{-1}$ air) as an active ingredient, was used as the positive control. The mortality percentage was determined after $24 \mathrm{~h}$ from the start of exposure.

The percentage of mortality was calculated using Equation 2:

$\%$ Mortality $=[(M T-M C) /(100-M C)] * 100$

where, $M T$ and $M C$ are the number of dead insects in the treated and control areas, respectively.

\section{Statistical analysis}

The results were converted into fumigant percentage and analyzed with ANOVA and Student $t$ tests. The mortality rates were calculated using the statistical formulas of Abbott and Probit to determine the $\mathrm{LC}_{50}$, chi-square values and related parameters. Biostat, a statistical program (Analyst Soft Robust Business Solutions, BioStat v 2009), was used with a confidence level of $5 \%$. Four replicates for each analysis were performed.

\section{RESULTS AND DISCUSSION}

The hydrodistillation technique isolated the essential oil from $P$. gorgonillense, and a yield of $0.14 \%$ was obtained, which, compared to other studies of this genus, was lower than the $0.21 \%$ seen with extraction with hydrodistillation of Piper corcovadensis EO (Miq.) (da Silva et al., 2016). Similarly, a study in Brazil obtained an essential oil yield of $0.44 \%$ with hydrodistillation extraction from Piper cubataonum (Santos et al., 2014); another study where oil was extracted with steam distillation from Piper hispidinervum saw
0.95\% (Sauter et al., 2012); finally, the essential oil yield from $P$. hispidinervum obtained with steam distillation reached $0.632 \%$ in a study by Andrés et al. (2017). The volatile chemical composition of $\mathrm{EO}$ is shown in table 1. Figure 1 shows the chemical structure of the main compounds of the $P$. gorgonillense essential oil.

After an intense bibliographic search, it was confirmed that this study is the first report on the volatile chemical composition of $P$. gorgonillense essential oil. The main compound found in this oil was $\beta$-caryophyllene, which is a cyclic sesquiterpene; these types of compounds are characterized by their unique structure, which has a bicyclo undecane ring system in the essential oil of a large variety of plant species. This compound is characterized as being volatile and aromatic with low solubility. It is recognized for deploying effective biological activities, such as anti-inflammatory, antiviral, anticarcinogenic, and antimutagenic, among other properties (De Oliveira-Tintino et al., 2018, Wu et al., 2018; Parisotto et al., 2020).

The chemical composition in this study differed slightly from the results obtained by other species belonging to the Piperaceae family, such as essential oil from Piper guineense with the following main components: $\beta$-sesquiphellandrene $(20.9 \%)$, linalool $(6.1 \%)$, limonene $(5.8 \%)$, Z- $\beta$-bisabolene $(5.4 \%)$ and $\alpha$-pinene (5.3\%) (Oyemitan et al., 2015); some of these compounds were found in the Piper gorgonillense $\mathrm{EO}$ but at a much lower proportion, for example, linalool $(0.6 \%)$, limonene $(0.2 \%)$ and $\alpha$-pinene $(0.2 \%)$. On the other hand, the oils extracted from Piper dilatatum had apiol $(79.0 \%)$, trans-caryophyllene $(8.3 \%)$, spathulenol (4.2\%) and $\gamma$-cadinene (1.7\%); Piper divaricatum EO had eugenol (37.5\%), methyl eugenol $(36.3 \%), \gamma$-elemene $(10.7 \%)$, asarone $(4.6 \%)$ and trans-caryophyllene (3.0\%); Piper aff. hispidum contained $\delta$-3-carene (9.6\%), p-cymene $(10.9 \%)$, limonene (17.2\%), elemol (14.1), $\gamma$-elemene $(7.3 \%)$ and $\beta$-eudesmol (5.7\%), whose composition markedly differs from that of Piper gorgonillense (Jaramillo-Colorado et al., 2019a).

Whereas, the Piper tuberculatum EO is composed of sesquiterpenes and their oxygenated derivatives, such as, (-)-spathulenol (11.37\%), $\alpha$-farnesene (6.22\%), (-)-humulene epoxide II ( 6.04\%), $\beta$-eudesmol $(4.36 \%), 2$-tridecanone (4.27\%), 2-pentadecanone $(4.06 \%)$, ledane $(3.62 \%), \quad(\mathrm{E}, \mathrm{E})$-farnesyl-acetone (3.55\%), $\beta$-cedrenoxide ( $2.96 \%), \alpha$-cadinol $(2.86 \%)$, 
Table 1. Volatile chemical composition of essential oil from Colombian $P$. gorgonillense.

\begin{tabular}{|c|c|c|c|c|}
\hline No & Compounds $^{\mathrm{a}}$ & RI $(\mathrm{HP}-5)^{\mathrm{b}}$ experimental & RI (HP-5) theoretical & Relative area $(\%)$ \\
\hline 1 & $\alpha$-Pinene & 935 & 939 & 0.2 \\
\hline 2 & Camphene & 950 & 954 & 0.3 \\
\hline 3 & $\beta$-Pinene & 968 & 979 & 0.5 \\
\hline 4 & Limonene & 1030 & 1029 & 0.2 \\
\hline 5 & Linalool & 1100 & 1096 & 0.6 \\
\hline 6 & Anisole & 1225 & 1232 & 0.2 \\
\hline 7 & $\delta$-Elemene & 1332 & 1335 & 0.6 \\
\hline 8 & 1,5,5-Trimethyl-6-methylene-cyclohexene & 1340 & 1338 & 1.8 \\
\hline 9 & $\alpha$-Cubebene & 1342 & 1345 & 1.3 \\
\hline 10 & $\alpha$-Copaene & 1368 & 1374 & 13.5 \\
\hline 11 & $\beta$-Bourbonene & 1380 & 1387 & 2.0 \\
\hline 12 & $\beta$-Elemene & 1385 & 1389 & 0.9 \\
\hline 13 & $\alpha$-Gurjunene & 1410 & 1409 & 2.7 \\
\hline 14 & $\beta$-Caryophyllene & 1425 & 1419 & 28.7 \\
\hline 15 & $\beta$-Gurjunene ( $\beta$-Calarene) & 1430 & 1433 & 3.2 \\
\hline 16 & Aromadendrene & 1444 & 1441 & 2.3 \\
\hline 17 & Humulene & 1450 & 1454 & 2.1 \\
\hline 18 & Allo-Aromadendrene & 1462 & 1460 & 1.3 \\
\hline 19 & $\gamma$-Muurolene & 1474 & 1479 & 1.6 \\
\hline 10 & Germacrene D & 1480 & 1484 & 1.0 \\
\hline 21 & trans-Muurola-4(14),5-diene & 1496 & 1493 & 2.1 \\
\hline 22 & $\alpha$-Muurolene & 1500 & 1500 & 2.7 \\
\hline 23 & Epi-bicyclosesquiphellandrene & 1515 & 1521 & 1.9 \\
\hline 24 & $\delta$-Cadinene & 1520 & 1523 & 7.3 \\
\hline 25 & $\alpha$-Cadinene & 1530 & 1538 & 1.1 \\
\hline 26 & $\alpha$-Calacorene & 1538 & 1544 & 1.7 \\
\hline 27 & Spathulenol & 1570 & 1578 & 2.5 \\
\hline 28 & Caryophyllene oxide & 1581 & 1583 & 0.9 \\
\hline 29 & Globulol & 1588 & 1590 & 1.7 \\
\hline 30 & Guaiol & 1596 & 1600 & 1.0 \\
\hline 31 & trans- $\beta$-Elemenone & 1600 & 1601 & 0.9 \\
\hline 32 & Cubenol <1-epi-> & 1622 & 1628 & 0.5 \\
\hline 33 & Cadin-4-en-7-ol <cis-> & 1628 & 1636 & 0.8 \\
\hline 34 & tau-Cadinol (epi- $\alpha$-cadinol) & 1636 & 1640 & 3.6 \\
\hline 35 & Epoxide-allo aromadendrene & 1639 & 1641 & 0.5 \\
\hline 36 & $\alpha$-Cadinol (tau-Muurolol) & 1645 & 1642 & 2.1 \\
\hline 37 & Cubenol & 1650 & 1646 & 1.4 \\
\hline 38 & Patchouli alcohol & 1656 & 1658 & 1.0 \\
\hline 39 & Eudesm-7(11)-en-4-ol (Juniper camphor) & 1720 & 1700 & 0.8 \\
\hline 40 & Phytol & 1932 & 1943 & 0.5 \\
\hline
\end{tabular}

${ }^{a}$ Identification made with mass spectrometry (El: electron impact ionization, $70 \mathrm{eV}$; peak matching $>90 \%$ ) and LRIs. Spectral databases wiley8, NIST08. ${ }^{b}$ Experimentally $\mathrm{Rl}$ on the HP-5, averages of three independent extractions. ${ }^{\mathrm{c}} \mathrm{Rl}$-Linear retention indices relative to $\mathrm{C}_{7}-\mathrm{C}_{30} \mathrm{n}$-alkanes. Forty compounds were identified, where sesquiterpenic type compounds predominated. The main components were $\alpha$-copaene (13.5\%), $\beta$-caryophyllene (28.7\%), $\delta$-cadinene $(7.3 \%)$ and tau-ca$\operatorname{dinol}(3.6 \%)$. 
dibutylphthalate (2.84\%), (1RS, 2SR) -2-hydroxy2,4,4-trimethyl-3- (3-methyl-3-butenylidene) cyclopentyl methyl ketone (2.68\%), 4-norpyridoxol (2.26\%), epiglobulol (2.14\%) and 8-acetyl-3, 3-epoxymethane-6,6,7-trimethylbicyclo $[5,1,0]$ octan2 -one $(2.11 \%)$ (Ordaz et al., 2011). In addition, the chemical identification of Piper marginatum had a higher percentage of sesquiterpenes; the main compounds included 3,4-methylenedioxyproprophenone $(22.90 \%), \delta$-3-carene $(10.19 \%)$, trans-caryophyllene (9.67\%) and spathulenol (6.89\%) (Gomes-Macêdo et al., 2020). However, the characterization of the essential oil from Piper aleyreanum saw a slight similarity in the composition of $P$. gorgonillense because sesquiterpenoids prevailed in $P$. aleyreanum, with $\beta$-elemene $(16.3 \%)$, bicyclogermacrene $(9.2 \%), \quad \delta$-elemene (8.2\%), germacrene D (6.9\%), $\beta$-caryophyllene (6.2\%) and spathulenol (5.2\%) as the main components; as for the Piper anonifolium oil, the composition was dominated by selin-11-en-4- $\alpha$-ol (20.0\%), $\beta$-selinene $(12.7 \%), \alpha$-selinene $(11.9 \%)$ and $\alpha$-pinene (8.8\%); and the Piper hispidum oil had $\beta$-caryophyllene $(10.5 \%)$, $\alpha$-humulene (9.5\%), $\delta$-3-carene $(9.1 \%), \alpha$-copane $(7.3 \%)$, limonene $(6.9 \%)$, caryophyllene oxide $(5.9 \%)$ and $\beta$-selinene (5.1\%) (da Silva et al., 2014).

Essential oils from the Piperaceae family are characterized by the presence of sesquiterpenes and derivatives of such oxygenates in their chemical composition; therefore, there are some similarities in the composition of these species (Chellappandian et al., 2018). Monoterpenes and sesquiterpenes are a significant and very versatile class of secondary metabolites that are commercially used in food, cosmetic, pharmaceutical, biotechnology, and agricultural industries, among others (Koyama et al., 2019).
Table 2 shows the results achieved for the repellent activity of the essential oil from $P$. gorgonillense on $T$. castaneum. The best repellent activity was at a concentration of $1 \%$, with a repellency percentage of $75 \pm 10 \%$ and $90 \pm 5 \%$ at 2 and $4 \mathrm{~h}$ of exposure, respectively. This was compared to the commercial DEET repellent ( $\mathrm{N}, \mathrm{N}$-diethyl-toluamide) at the same concentration with an activity of $76 \pm 6 \%$ during the first $2 \mathrm{~h}$ and $78 \pm 5 \%$ after $4 \mathrm{~h}$ (Tab. 2). These results show that the $P$. gorgonillense EO exhibited a higher repellent activity than the commercial repellent.

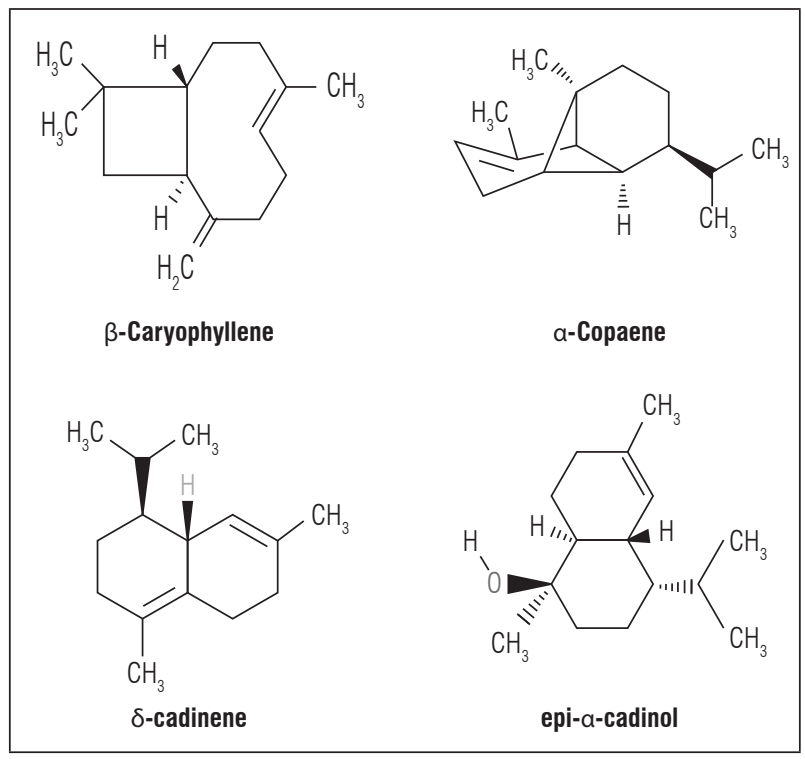

Figure 1. Chemical structure of the main compounds of the essential oil from $P$. gorgonillense. Source: MarvinSketch.

Table 2. Repellent activity of the essential oil from $P$ gorgonillense against $T$. castaneum.

\begin{tabular}{|c|c|c|c|}
\hline \multirow{2}{*}{ Sample } & \multirow{2}{*}{ Concentration (\%) } & \multicolumn{2}{|c|}{ Repellency (\%) } \\
\hline & & Exposure time $2 \mathrm{~h}$ & Exposure time $4 \mathrm{~h}$ \\
\hline Piper gorgonillense EO & $\begin{array}{c}0.0001 \\
0.001 \\
0.01 \\
0.1 \\
1.0\end{array}$ & $\begin{array}{l}16 \pm 5 \\
32 \pm 8 \\
56 \pm 5 \\
68 \pm 4 \\
78 \pm 8\end{array}$ & $\begin{array}{l}24 \pm 5 \\
36 \pm 5 \\
64 \pm 5 \\
74 \pm 5 \\
90 \pm 7\end{array}$ \\
\hline $\begin{array}{l}\text { N,N-diethyl-toluamide } \\
\text { (DEET) }\end{array}$ & $\begin{array}{c}0.0001 \\
0.001 \\
0.01 \\
0.1 \\
1.0\end{array}$ & $\begin{array}{c}10 \pm 5 \\
16 \pm 5 \\
40 \pm 10 \\
50 \pm 5 \\
76 \pm 6\end{array}$ & $\begin{array}{c}16 \pm 5 \\
18 \pm 8 \\
57 \pm 13 \\
59 \pm 11 \\
78 \pm 5\end{array}$ \\
\hline
\end{tabular}

Repellent values $=$ mean \pm SE of the four replicates (SE $=$ standard error). Paired $t$ test $(P<0.05)$. 
After a statistical analysis of repellent activity results, bilateral significance was obtained with a value greater than 0.005 , which were 0.106 at $2 \mathrm{~h}$ of exposure and 0.109 at $4 \mathrm{~h}$ of exposure; the intervals of confidence were $[(-2.55464)-(25.75464)]$ and $[(-2.78010)$ - (26.78010)] for 2 and 4 h of exposure, respectively. Lastly, the t-test showed an equal value for the two trials: the P. gorgonillense EO and DEET, with 1,648 at $2 \mathrm{~h}$ and 1,632 at $4 \mathrm{~h}$ for both. This analysis allowed us to infer that the P. gorgonillense EO and DEET had similar behaviors; therefore, it is possible to infer that the oil has a repellent activity very similar to that of a commercial repellent.

$\beta$-Caryophyllene has shown repellent activity against Aedes aegypti and Anopheles minimus (Nararak et al., 2019), as well as against Sitophilus granarius (Plata et al., 2018). In the study reported by Parisotto et al. (2020), $\beta$-caryophyllene acted as a powerful anti-inflammatory agent and demonstrated efficiency in the repair of skin tissue; $\beta$-caryophyllene provided anti-inflammatory and antiedemagnetic activity in in vivo tests of acute and chronic inflammation through a series of laboratory tests (De Oliveira-Tintino et al., 2018). $\beta$-caryophyllene has shown an effective action against parasites such as Trypanosoma cruzi and Leishmania brasiliensis. Thanks to these results, this compound is considered an alternative against the aforementioned species (Leite et al., 2013), i.e., $\delta$-cadinene deployed larvicidal activity against the malaria vector Anopheles stephensi, (Govindarajan et al., 2016). $\alpha$-copaene has been evaluated as an insecticide against different types of insects, including the beetle, Xyleborus glabratus Eichhoff (Kendra et al., 2016), the beetle Euwallacea fornicatus Eichhoff (Kendra et al., 2017), the fly Bactrocera oleae (Rossi) (de Alfonso et al., 2014), and Ceratitis capitata (Flat et al., 1994).
Different $\delta$-cadinene activities have also been reported, such as anticancer (Xu et al., 2015), antifungal (Kundu et al., 2013), and acaricidal activities (Guo et al., 2017).

The fumigant activity results for the $P$. gorgonillense essential oil are shown in figure 2 . The $P$. gorgonillense EO reached a fumigant activity of $100 \%$ at a concentration of $350 \mu \mathrm{g} \mathrm{mL}^{-1}$ air. Essential oils are considered fumigants because of their physical properties of low molecular weight, low boiling point and high volatility (Zhang et al., 2017).

Table 3 presents the mean lethal concentrations (LC50) obtained for the essential oil of $P$. gorgonillense in three exposure periods. The fumigant toxicity of the EO was evaluated on adult T. castaneum weevils. The results of the probit analysis showed that the pyrimiphos methyl (positive control), at $24 \mathrm{~h}$ of exposure, obtained an $\mathrm{LC}_{50}=188,673 \mu \mathrm{g} \mathrm{mL}-1$ air, $\mathrm{LC}_{50}=84.2145 \mu \mathrm{g} \mathrm{mL}^{-1}$ air at $48 \mathrm{~h}$, and $\mathrm{LC}_{50}=68.0253$ at $72 \mathrm{~h}$, with pirimiphos-methyl being 2.3493 times more toxic in the first $24 \mathrm{~h}, 4.13622$ times, more toxic in the first $48 \mathrm{~h}$ and 3.4261 times more lethal than the studied essential because the $P$. gorgonillense $\mathrm{EO}$ yielded an $\mathrm{LC}_{50}=443.262 \mu \mathrm{g} \mathrm{mL}^{-1}$ air at $24 \mathrm{~h}$, an $\mathrm{LC}_{50}=348,328 \mu \mathrm{g} \mathrm{mL}-1$ air at $48 \mathrm{~h}$ and an $\mathrm{LC}_{50}=$ $233,066 \mu \mathrm{g} \mathrm{mL}^{-1}$ air at $72 \mathrm{~h}$ of exposure.

On the other hand, several studies have reported the repellent and/or insecticidal activity of essential oils from plants of the Piper genus on Tribolium castaneum, i.e. Piper nigrum, Piper dilatatum, Piper aduncum, Piper divericatum and Piper sp. (Scott et al., 2008; JaramilloColorado et al., 2019a); P. guineense (Adarkwah et al., 2018); and Piper cubeba (Chaubey, 2011); among others. The $P$. gorgonillense EO evaluated in this study

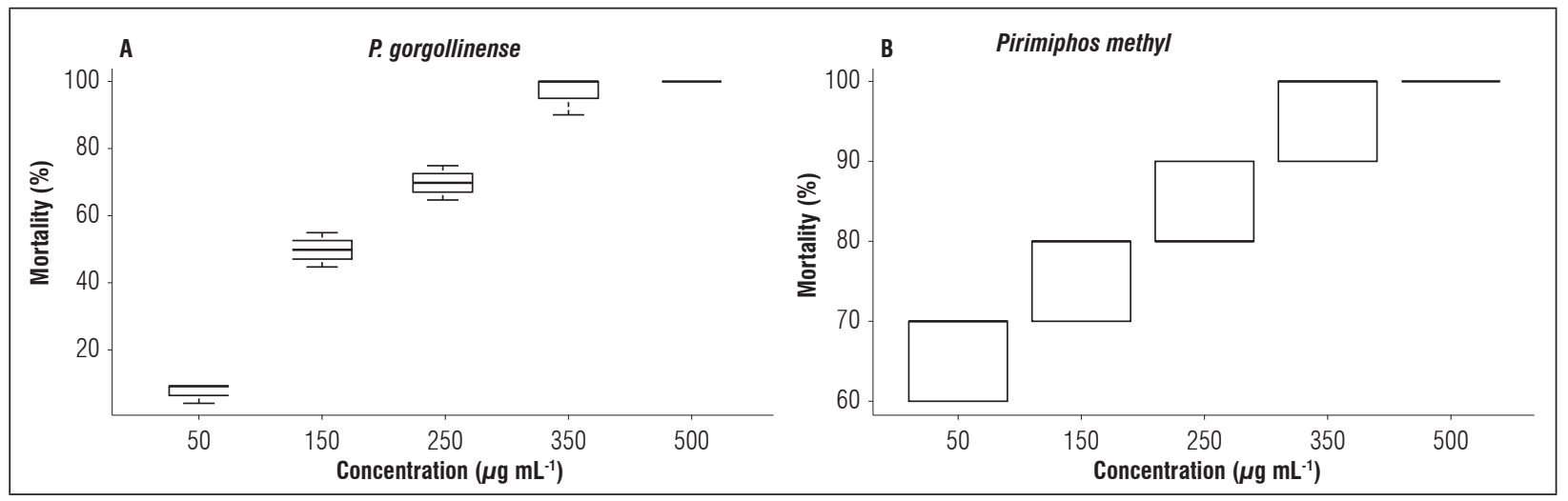

Figure 2. Fumigant activity of $P$ gorgonillense essential oil and pirimiphos methyl. 
Table 3. Toxicity of the essential oil $P$. gorgonillense and pirimiphos- methyl against $T$. castaneum.

\begin{tabular}{|l|c|c|c|c|c|}
\hline Treatments, $n=5$ & Period $(\mathrm{h})$ & LC $_{50}(95 \% \mathrm{FL})$ & LC $_{95}(95 \% \mathrm{FL})$ & $X^{2}$ (df) & Slope $\pm \mathrm{SE}$ \\
\hline \multirow{3}{*}{ P. gorgonillense } & 24 & $443.262[395.696 ; 495.943]$ & $938.338[831.046 ; 1100.81]$ & $8.345(3)$ & $1.79 \pm 0.18$ \\
\cline { 2 - 7 } & 48 & $348.328[315.464 ; 382.645]$ & $671.424[608.674 ; 760.233]$ & $6.776(3)$ & $1.77 \pm 0.17$ \\
\cline { 2 - 7 } & 72 & $233.066[202.345 ; 262.862]$ & $515.145[465.407 ; 583.398]$ & $4.011(2)$ & $1.35 \pm 0.16$ \\
\hline \multirow{3}{*}{$\begin{array}{l}\text { Commercial insecticide } \\
\text { (methyl pirimiphos) }\end{array}$} & 24 & $188.673[114.824 ; 246.333]$ & $333.766[277.547 ; 394.697]$ & $1.449(3)$ & $0.0198 \pm 0.0015$ \\
\cline { 2 - 7 } & 48 & $84.2145[77.023 ; 147.414]$ & $216.133[207.333 ; 320.308]$ & $1.758(3)$ & $0.0159 \pm 0.0015$ \\
\cline { 2 - 7 } & 72 & $68.0253[54.157 ; 79.856]$ & $153.084[143.502 ; 177.335]$ & $0.193(2)$ & $0.0136 \pm 0.0012$ \\
\hline
\end{tabular}

showed significant fumigant and repellent activity. According to the literature, the major sesquiterpenes found in the oil, such as $\beta$-caryophyllene, $\alpha$-copaene and $\delta$-cadinene, have exhibited insecticidal and/or repellent properties. Kim et al. (2010) reported that the fumigant and repellent activity of essential oils are related to the presence of monoterpenes, such as $\alpha$-pinene, $\delta$-cymene, carvacrol thymol, and $\alpha$-and myrcene, and sesquiterpene compounds, such as caryophyllene oxide and caryophyllene (Kim et al., 2010).

\section{CONCLUSION}

The results showed that the essential oil of $P$. gorgonillense and its terpenoid components deploy fumigant and repellent activity against $T$. castaneum, suggesting its potential for protecting stored grains.

\section{ACKNOWLEDGEMENTS}

The authors thank the Ministry of Science, Technology and Innovation, the Ministry of Education, the Ministry of Industry, Commerce and Tourism, and ICETEX for funding this study through the Programme Ecosistema Científico-Colombia Científica from the Francisco José de Caldas Fund, Grand RCFP44842-212-2018, Research Groups Support Program - Research Vicepresidency at the Universidad de Cartagena (2015-2019).

Conflict of interests: The manuscript was prepared and reviewed with the participation of the authors, who declare that there exists no conflict of interest that puts at risk the validity of the presented results.

\section{BIBLIOGRAPHIC REFERENCES}

Adams, R.P. 2007. Identification of essential oil components by gas chromatography/ mass spectroscopy. $4^{\text {th }}$ ed. Allured Publishing, Carol Stream, IL.

Adamski, Z., S.A. Bufo, S. Chowański, P. Falabella, J. Lubawy, P. Marciniak, J. Pacholska-Bogalska, R. Salvia, L. Scrano, M. Słocińska, M. Spochacz, M. Szymczak, A. Urbański, K. Walkowiak-Nowicka, and G. Rosiński. 2019. Beetles as model organisms in physiological, biomedical and environmental studies. A review. Front Physiol. 10, 319. Doi: 10.3389/fphys.2019.00319

Adarkwah, C., D. Obeng, and S. Prozell. 2018. Toxicity and protectant potential of Piper guineense (Piperaceae) and Senna siamea (Fabaceae) mixed with diatomaceous earth for the management of three major stored product beetle pests. Int. J. Pest Manage. 64, 128-139. Doi: 10.1080/09670874.2017.1346327.

Andrés, M.F., G.E. Rossa, E. Cassel, R.M.F. Vargas, O. Santana, C.E. Díaz, and A. González. 2017. Biocidal effects of Piper hispidinervum (Piperaceae) essential oil and synergism among its main components. Food Chem. Toxicol. 109, 1086-1092. Doi: 10.1016/j. fct.2017.04.017

Athanassiou, C.G., N.G. Kavallieratos, and J.F. Campbell. 2016. Capture of Tribolium castaneum and Tribolium confusum (Coleoptera: Tenebrionidae) in floor traps: the effect of previous captures. J. Econ. Entomol. 109(1), 461-466. Doi: 10.1093/jee/tov307.

Chaubey, M.K. 2011. Insecticidal properties of Zingiber officinale and Piper cubeba essential oils against Tribolium castaneum Herbst (Coleoptera: Tenebrionidae). J. Biol. Active Prod. Nature 1, (5-6), 306-313. Doi: 10.1080/22311866.2011.10719098

Chellappandian, M., P. Vasantha, S. Senthil, S. Karthi, A. Thanigaivel, A. Ponsankar, and W.B. Hunter. 2018. Botanical essential oils and uses as mosquitocides and repellents against dengue. Environ. Int. 113, 214-230. Doi: 10.1016/j.envint.2017.12.038. 
Daglish, G.J., M.K. Nayak, H. Pavic, and L.W. Smith. 2015. Prevalence and potential fitness cost of weak phosphine resistance in Tribolium castaneum (Herbst) in eastern Australia. J. Stored Prod. Res. 61, 54-58. Doi: 10.1016/j.jspr.2014.11.005

Da Silva, J.K.R., L.C. Pinto, R.M.R. Burbano, R.C. Montenegro, E.F. Guimarães, E.H.A. Andrade, and J.G.S. Maia. 2014. Essential oils of Amazon Piper species and their cytotoxic, antifungal, antioxidant and anti-cholinesterase activities. Ind. Crops Prod. 58, 55-60. 10.1016/j.indcrop.2014.04.006

Da Silva, M.F.R., P.C. Bezerra, C.S. de Lira, A.B.N. de Lima, A.C.A. Neto, E.V. Pontual, and D.M.D. Navarro. 2016. Composition and biological activities of the essential oil of Piper corcovadensis (Miq.) C. DC (Piperaceae). Exp. Parasitol. 165, 64-70. Doi: 10.1016/j. exppara.2016.03.017

De Alfonso, I., S. Vacas, and J. Primo. 2014. Role of $\alpha$-copaene in the susceptibility of olive fruits to Bactrocera Oleae (Rossi). J. Agric. Food Chem. 62(49), 1197611979. Doi: 10.1021/jf504821a

De Oliveira-Tintino, C., R.T. Pessoa, M. Fernandes, I. Alcântara, B. Silva, M. Oliveira, A. Martins, M. Silva, S. Tintino, F. Rodrigues, J. Costa, S. Lima, M. Kerntopf, T. Silva, and I. Menezes. 2018. Anti-inflammatory and anti-edematogenic action of the Croton campestris A. St.-Hil (Euphorbiaceae) essential oil and the compound $\beta$-caryophyllene in in vivo models. Phytomedicine 41, 82-95. Doi: 10.1016/j.phymed.2018.02.004

Flat, R.A., R.T. Cunningham, T.R. Mon, and J.O. John. 1994. Male lures for mediterranean fruitfly (Ceratitis capitata Wied.): Structural analogs of $\alpha$-copaene. J. Chem. Ecol. 20(10), 2595-609. Doi: 10.1007/BF02036194

Gamboa, F., C.C. Muñoz, G. Numpaque, L.G. Sequeda, S.J. Gutierrez, and N. Tellez. 2018. Antimicrobial activity of Piper marginatum Jacq and Ilex guayusa Loes on microorganisms associated with periodontal disease. Int. J. Microbiol. 2018, 4147383-4147392. Doi: 10.1155/2018/4147383

Govindarajan, M., M. Rajeswary, and G. Benelli. 2016. $\delta$-cadinene, calarene and $\delta$-4-carene from Kadsura heteroclita essential oil as novel larvicides against malaria, dengue and filariasis mosquitoes. Comb. Chem. High Throughput Screen. 19(7), 565-571. Doi: 10.2174/138 6207319666160506123520

Guo, X., X. Shang, B. Li, X.Z. Zhou, H. Wen, and J. Zhang. 2017. Acaricidal activities of the essential oil from Rhododendron nivale Hook. f. and its main compund, $\delta$-cadinene against Psoroptes cuniculi. J. Vet. Parasitol. 236, 51-54. Doi: 10.1016/j.vetpar.2017.01.028

Idárraga, A. and R. Callejas. 2011. Análisis florístico de la vegetación del Departamento de Antioquia. In: Idárraga, A., R. del C. Ortiz, R. Callejas, and M. Mere1lo (eds.). Flora de Antioquia: catálogo de las plantas vasculares. vol. II. Listado de las plantas vasculares del departamento de Antioquia. Programa Expedición Antioquia-2103. Series Biodiversidad y Recursos Naturales. Universidad de Antioquia; Missouri Botanical Garden; Oficina de Planeación Departamental de la gobernación de Antioquia, Editorial D’Vinni, Bogota.

Jaramillo-Colorado, B., I. Martelo, and E. Duarte. 2012. Antioxidant and repellent activities of the essential oil from Colombian Triphasia trifolia (Burm. f.) P. Wilson. J. Agric. Food Chem. 60, 6364-6368. Doi: 10.1021/ jf300461k

Jaramillo-Colorado, B.E., N. Pino, and A. Gonzalez. 2019a. Volatile composition and biocidal (antifeedant and phytotoxic) activity of the essential oils of four Piperaceae species from Choco-Colombia. Ind. Crops Prod. 138, 111463. 10.1016/j.indcrop.2019.06.026

Jaramillo-Colorado, B.E., S.A. Suarez, and V. Marrugo. 2019b. Volatile chemical composition of essential oil from Bursera graveolens (Kunth) Triana \& Planch and their fumigant and repellent activities. Acta Sci. Biol. Sci. 41, e46822. Doi: 10.4025/actascibiolsci. v41i1.46822

Jaramillo, B.E., F.M. Palacio, and E. Duarte. 2020. Antioxidant and biological activities of essential oil from Colombian Swinglea glutinosa (Blanco) Merr fruit. Acta Sci. Biol. Sci, 42, e51639. Doi: 10.4025/actascibiolsci.v42i1.51639.

Kendra, P.E., D. Owens, W.S. Montgomery, T.I. Narvaez, G.R. Bauchan, E.O. Schnell, N. Tabanca, and D. Carrillo. 2017. $\alpha$-Copaene is an attractant, synergistic with quercivorol, for improved detection of Euwallacea nr. fornicatus (Coleoptera: Curculionidae: Scolytinae). PLoS One 12(6), e0179416. Doi: 10.1371/journal. pone.0179416

Kendra, P.E., W.S. Montgomery, E.Q. Schnell, M.A. Deyrup, and N.D. Epsky. 2016. Efficacy of $\alpha$-copaene, cubeb, and eucalyptol lures for detection of redbay Ambrosia beetle (Coleoptera: Curculionidae: Scolytinae). J. Econ. Entomol. 109(6), 2428-2435. Doi: 10.1093/jee/tow214

Kim, S.-I., J.-S. Yoon, J.W. Jung, K.-B. Hong, Y.-J. Ahn, and H.W. Kwon. 2010. Toxicity and repellency of origanum essential oil and its components against Tribolium castaneum (Coleoptera: Tenebrionidae) adults. J. Asia-Pac. Entomol. 13(4), 369-373. Doi: 10.1016/j. aspen.2010.06.011

Koyama, S., A. Purk, M. Kaur, H.A. Soini M.V. Novotny, K. Davis, C. Kao, H. Matsunami, and A. Mescher. 2019. Beta-caryophyllene enhances wound healing through multiple routes. PLoS ONE 14(12), e0216104. 10.1371/journal.pone.0216104

Kundu, A., S.S. Walia, N.A. Shakil, J. Kumar, and K. Annapurna. 2013. Cadinene sesquiterpenes from Eupatorium adenophorum and their antifungal activity. J. Environ. Sci. Health B. 48(6), 516-22. Doi: 10.1080/03601234.2013.761921 
Leite, N.F., C.E. Sobral, R.S. Albuquerque, D.I. Brito, A.K. Lavor, L.B. Alencar, S.R. Tintino, J.V.A. Ferreira, F.G. Figueredo, L.F. Lima, F.A.B. Cunha, A.I. Pinho, and H.D.M. Coutinho 2013. Actividad antiparasitaria in vitro citotóxica de cariofileno y eugenol contra Trypanosoma cruzi y Leishmania brasiliensis. Rev. Cuba. Plantas Med. 18(4), 522-528.

Gomes-Macêdo, C.G., M.Y.N. Fonseca, A.D. Caldeira, S.P. Castro, W. Pacienza, M.P.G. Borsodi, A. Sartoratto, M. Silva, C. Salgado, B. Rossi-Bergmann, and K.C.F. Castro. 2020. Leishmanicidal activity of Piper marginatum Jacq. from Santarém-PA against Leishmania amazonensis. Exp. Parasitol. 210, 107847. Doi: 10.1016/j. exppara.2020.107847

Nararak, J., S. Sathantriphop, and M. Kongmee. 2019. Excito-repellent activity of $\beta$-Caryophyllene oxide against Aedes aegypti and Anopheles minimus. Acta Trop. 197, 105030. Doi: 10.1016/j.actatropica.2019.05.021

Opit, G.P., T.W. Phillips, M.J. Aikins, and M.M. Hasan. 2012. Phosphine resistance in Tribolium castaneum and Rhyzopertha dominica from stored wheat in Oklahoma. J. Econ. Entomol. 105, 1107-1114. Doi: 10.1603/ ec12064

Ordaz, G., H. D’Armas, D. Yáñez, and S. Moreno. 2011. Composición química de los aceites esenciales de las hojas de Helicteres guazumifolia (Sterculiaceae), Piper tuberculatum (Piperaceae), Scoparia dulcis (Arecaceae) y Solanum subinerme (Solanaceae), recolectadas en Sucre, Venezuela. Rev. Biol. Trop. 59(2), 585-595.

Oyemitan, I.A., O.A. Olayera, A. Alabi, L.A. Abass, C.A. Elusiyan, A.O. Oyedeji, and M.A. Akanmu. 2015. Psychoneuropharmacological activities and chemical composition of essential oil of fresh fruits of Piper guineense (Piperaceae) in mice. J. Ethnopharmacol. 166, 240-249. Doi: 10.1016/j.jep.2015.03.004

Parisotto, J., J. Bidone, L.G. Lucca, G. Araújo, M. Falkembach, M. Marques, A. Horn, M. Santos, V. Veiga Jr., R. Limberger, H. Teixeira, C. Dora, and L. Koester. 2020. Healing activity of hydrogel containing nanoemulsified $\beta$-caryophyllene. Eur. J. Pharm. Sci. 148, 105318. Doi: 10.1016/j.ejps.2020.105318

Parra, J.E., L.E. Cuca, and A. González. 2019. Antifungal and phytotoxic activity of benzoic acid derivatives from inflorescences of Piper cumanense. Nat. Prod. Res. Doi: 10.1080/14786419.2019.1662010

Plata, A., J. Mendonça Campos, G. Silva Rolim. L.C. Martínez, M. Santos, F. Fernandes, J. Serrão, and J. Zanuncio. 2018. Terpenoid constituents of cinnamon and clove essential oils cause toxic effects and behavior repellency response on granary weevil, Sitophilus granaries. Ecotoxicol. Environ. Saf. 156, 263-270. Doi: 10.1016/j.ecoenv.2018.03.033

Rengifo, A.M., L.M. Muñoz, F.A. Cabezas, and J.A. Guerrero. 2019. Edematic and coagulant effects caused by the venom of Bothrops rhombeatus neutralized by the ethanolic extract of Piper auritum. J. Ethnopharmacol. 242, 112046. Doi: 10.1016/j.jep.2019.112046

Santos, T.G., K. Fukuda, M.J. Kato, A. Sartorato, M.C. Duarte, A.L.T. Ruiz, J. Carvalho, F. Augusto, F. Marques, and B.H.L.S. Maia. 2014. Characterization of the essential oils of two species of Piperaceae by one- and two-dimensional chromatographic techniques with quadrupole mass spectrometric detection. Microchem. J. 115, 113-120. 10.1016/j.microc.2014.02.014

Sauter, I.P., G.E. Rossa, A.M. Lucas, S.P. Cibulski, P.M. Roehe, L.A.A. da Silva, M. Rott, R. Vargas, E. Cassel, and G.L. von Poser. 2012. Chemical composition and amoebicidal activity of Piper hispidinervum (Piperaceae) essential oil. Ind. Prod. Crops. 40, 292-295. Doi: 10.1016/j.indcrop.2012.03.025.

Scott, I.M., H.R. Jensen, B.J. Philogène, and J.T. Arnason. 2008. A review of Piper spp. (Piperaceae) phytochemistry, insecticidal activity and mode of action. Phytochem. Rev. 7(1), 65. Doi: 10.1007/s11101-006-9058-5.

Singh, P. and A.K. Pandey. 2018. Prospective of essential oils of the genus Mentha as biopesticides: A review. Front. Plant Sci. 9, 1295. Doi: 10.3389/fpls.2018.01295.

The Plant List. 2013. Version 1.1. Piper gorgonillense. Dabase in: http://www.theplantlist.org/tpl1.1/record/tro50088832; consulted: April, 2020.

Wu, W., F. Liu, and R.W. Davis. 2018. Engineering Escherichia coli for the production of terpene mixture enriched in caryophyllene and caryophyllene alcohol as potential aviation fuel compounds. Metab. Eng. Commun. 6, 13-21. Doi: 10.1016/j.meteno.2018.01.001

Xu, G.L., D. Geng, M. Xie, K.Y. Teng, Y.X. Tian, Z.Z. Liu, C. Yan, Y. Wang, X. Zhang, Y. Song, Y. Yang, and G.M. She. 2015. Chemical composition, antioxidative and anticancer activities of the essential oil: Curcumae Rhizoma-Sparganii Rhizoma, a traditional herb pair. Molecules 20(9), 15781-15796. 10.3390/ molecules200915781

Zhang, Z., Y. Xie, Y. Wang, Z. Lin, L. Wang, and G. Li. 2017. Toxicities of monoterpenes against housefly, Musca domestica L. (Diptera: Muscidae). Environ. Sci. Pollut. Res. 24(31), 24708-24713. Doi: 10.1007/ s00436-012-3105-5 